\title{
Basilar dolichoectasia with otorhinolaryngological symptoms: A case report
}

\author{
Tuani A. Stroke, ${ }^{1 \star}$ Ana Cristina C. Martins ${ }_{,}^{1,2}$ Lucas A. L. T. Silva, ${ }^{1}$ Henrique José C. Artigoza, ${ }^{1}$ Annelise O. A. \\ B. Figueira, ${ }^{1}$ Fernando José M. Mendes, ${ }^{1}$ Rafael Hollanda ${ }^{3}$
}

\begin{abstract}
Introduction: Basilar dolicoectasis is an uncommon change, which makes the vessel tortuous and dilated, which can lead to ischemic, hemorrhagic or compressive changes. Objective: The present study is case report of a patient with basilar artery dolicoectasis and otorhinolaryngological symptoms. Clinical Case: Patient, 53 years old, male, smoker, hypertensive, atrial fibrillation and gout, who after hospitalization due to stroke suffered a complaint of hearing loss, facial paralysis and dizziness. During hospitalization, he was diagnosed with basilar artery dolichoectasia. Conclusion: Basilar artery dolichoectasia is rare, the otorhinolaryngologist should be aware of vascular causes when evaluating a patient with otoneurological symptoms. The treatment of basilar artery dolichoectasis remains controversial.
\end{abstract}

Keywords: Stroke; Basilar dolicoectasis; Basilar megadolism; Hearing loss; Peripheral facial paralysis; Dizziness.

\section{Resumo}

Dolicoectasia Basilar com alterações otorrinolaringológicas: Um relato de caso

Introdução: A dolicoectasia basilar é uma alteração incomum, que torna o vaso tortuoso e dilatado que pode levar a alterações isquêmicas, hemorrágicas ou compressivas. Objetivo: Relatar um caso de dolicoectasia da artéria basilar com sintomas otorrinolaringológicos. Caso Clínico: Homem, 53 anos, tabagista, hipertenso, fibrilação atrial e gota, o qual após internação hospitalar por acidente vascular encefálico evoluiu com hipoacusia, paralisia facial e tontura, quando, neste período, foi diagnosticado com dolicoectasia da artéria basilar. Conclusão: A dolicoectasia da artéria basilar é uma entidade rara. $\mathrm{O}$ otorrinolaringologista deve estar atento às causas vasculares quando avaliar um paciente com sintomas otoneurológicos. O tratamento permanece controverso.

Descritores: Acidente vascular encefálico; Dolicoectasia basilar; Megadolico basilar; Perda auditiva; Paralisia facial periférica; Tontura.
1. Posgraduate studies in Otorhinolaryngology, Specialized Service in Otorhinolaaryngological Prevention and Treatment (SEPTO). Pontifical Catholic University of Rio de Janeiro, RJ, Brazil.

2. Otorhinolaryngology Departament. Oswaldo Cruz Foundation (Fiocruz), Rio de Janeiro, RJ, Brazil.

3. Radiology Departament. Casa de Portugal Hospital, Rio de Janeiro, RJ, Brasil.

*Correspondence address:

240, Andrade Neves st. 404

Rio de Janeiro, RJ, Brazil.

Zip Code: 20510230

E-mail: tuanistroke@hotmail.com

ORCID: https://orcid.org/0000-0001-8421-8557

BJHBS, Rio de Janeiro, 2020;19(2):151-155

Received on 26/08/2020. Approved on 17/09/2020.

\section{Resumen}

Dolicoectasia basilar com alteraciones otorrinolaringológicas: Reporte de un caso

Introducción: La dolicoectasia basilar es una alteración infrecuente, que torna el vaso tortuoso y dilatado, pudiendo ocasionar cambios isquémicos, hemorrágicos o compresivos. Objetivo: El presente estudio tiene como objetivo reportar el caso de un paciente con cuadro de dolicoectasia de arteria basilar con sintomatología otorrinolaringológica. Caso clínico: Paciente de 53 años, varón, fumador, hipertenso, con fibrilación auricular y gota, que tras ser hospitalizado por ictus sufrió un cuadro de hipoacusia, parálisis facial y mareos. Durante la hospitalización se le diagnosticó un cuadro de dolicoectasia de la arteria basilar. Conclusión: La dolicoectasia de la arteria basilar es una entidad poco frecuente. El otorrinolaringólogo debe conocer las causas vasculares al evaluar a un paciente con síntomas otoneurológicos. Su tratamiento sigue siendo controvertido.

Palabras clave: Ictus; Dolicoectasia basilar; Megadolismo basilar; Hipoacusia; Parálisis facial periférica; Mareos. 


\section{Clinical Case}

\section{Introduction}

Basilar artery dolichoectasia is rare vasculopathy with unknown etiology. It occurs due to anatomical modifications that makes the basilar artery elongated, tortuos and sometimes aneurysmatic. When symptomatic, it is presented with hemodynamic disorders or compressive effects. ${ }^{1}$ Also, it can affect the emerge site of the cranial nerves. The most affected cranial nerves are $\mathrm{V}$ and VII pairs, which leads to trigeminal neuralgia and hemifacial paralysis, respectively. The compressive effect of the VIII pair leads to a clinical condition called vestibular paroxysm.

The magnetic resonance imaging (MRI) is the most common exam, in which is possible to observe the caliber of the vessel, its aberrant shape, and possible affected structures.

Treatment can be conservative or intervencional, and it is necessary a multidisciplinary approach, with na otorhinolaryngologist, neurologista and neurosurgeon. $^{2}$

\section{Case Report}

C.P, 53 years old, male, smoker, engeneer professional, came to the specialized service of otorhinolaryngology after hospitalization due to acute ischemic event, complaning of hearing loss, facial paralisys and dizziness.

He had a past pathological history of a long term hearing lost in the right ear, with no defined ethiology (before the ischemic event), and was treated for systemic arterial hypertension, arterial fibrillation and gout.

The otorhinolaringological physical exam revealed intact bilateral tympanic membranes, rhinoscopy and oroscopy with no alterations, peripheral facial paralisys on the left side House-Brackmann classification level IV, Romberg test falling to the right side, Fukuda test with ataxic gait, spontaneous nistagmus to the right, head impulse test with corrective saccades to the right.

The paciente brought the MRI and agioresonance performed during the hopitalization time, which showed acute ischemic lesion in the pons and in the base of the left cerebelar hemisphere. Dolichoectasia of the basilar artery, with tortuos path through almost all of its extension, with fusiform aneurysmatic dilatation in the adjacent segment to the transition beteween the bulb and the pons on the right, which determined extrinsec compression on the pons.

The audiometry performed during hospitalization had moderate to severe sensorioneural loss in the right ear and moderate to profound sensorioneural loss in the left ear. Immitance testing showed type A curves and absent contralateral acoustic reflexes.

On the day of the medical appointment, a second audiometry was performed to evaluate the current situation. The right ear presented moderated to severe sensorioneural loss and the left ear presented mild to moderate sensorioneural loss. There was no discrimination in the right ear. Immitance testing showed type A curves in both ears.

After discussing the case, it was decided, at first, to iniciate treatment with thiamine nitrate compound (B1 vitamin) with pyridoxine hydrocloride (B6 vitamin) $5000 \mathrm{IU}, 1$ tablet once a day for 60 days, E vitamin 400 IU, 1 tablet every 12 hours for 30 days, A vitamin 50000 IU 1 tablet every 12 hours for 30 days and D vitamin 1 tablet every 12 hours for 30 days, flunarizine dihydrochloride with dihydroergocrisine mesylate 1 tablet every 12 hours for 5 days gradually decreasing 1 tablet once a day for another 10 days, and finally, dexamethasone $4 \mathrm{mg}$, 2 tablets in the mornign for 7 days, followed by its reduction to 1 tablet once a day for 5 days and later half tablet for 2 more days.

The following complementary exams were requested: brainstem evoked response audiometry (BERA), eletrocochleography (ECochG), and vectoelectronystamography. In addition, the need for neurological and physical therapy monitoring was reforced. After the end of the treatment, serial audiometries were performed for follow-up, and maintenence treatment was started with betahistine $24 \mathrm{mg} 1$ tablet every 12 hours.

The third audiometry (performed after the treatment) showed an improvement with moderate sensorioneural loss in the right ear and mild sensorioneural loss in the left ear.

The ECochG exam showed endolinphatic hydrops in the right ear.

BERA, on the other hand, showed suggestive signs of retrocochlear disfunction for both ears (more evidently for the right ear). The exam suggested psycoacoustic threshold of $75 \mathrm{Db} \mathrm{Nhl}$ (approx. 65 - $70 \mathrm{~dB} \mathrm{NA}$ ) for the tested frequency range $(2000-4000 \mathrm{~Hz})$ for the right ear, and psycoacoustic threshold of $60 \mathrm{Db} \mathrm{Nhl}$ (approx. 55 $60 \mathrm{~dB} N \mathrm{NA})$ for the tested frequency range (2000 - 4000 $\mathrm{Hz}$ ) for the left ear.

The vectoeletronistagmography exam showed spontaneous nystagmus to the right and semispontaneous nystagmus to the right with positive DixHallpike to the right and caloric test without dizziness with the predominance of the labyrinth to the left. 
With the results of complementary exams and the patient's clinical history, it was decided for the use of hearing aids.

After the fourth audiometry, already in use of hearing aids, the result showed mild to moderate sensorioneural loss to the right ear and mild to moderate sensorioneural loss to the left ear. Discrimitation was absent in the right ear. A free field audiometry was performed with the use of hearing aids to verify the auditory gain.

On the following routine appointments the patient still complained of ocasional mild dizziness. It was indicated vestibular rehabilitation therapy. However, the patient did not return to follow-up.

\section{Discussion}

Basilar dolichoectasia is a clinical entity defined as vascular dilation and tortuosity. The incidence of intracranial dolichoectatic vassels varies between $0.06-5.8 \%$. Vertebral and basilar arteries are the most affected. ${ }^{3}$ In about $40 \%$ of the cases, this alterations is asymptomatic and it's a radiological finding. ${ }^{4}$ Its prevalence increases with age and it is associated with cardiovascular risk factors and the male gender. ${ }^{5}$

Genetic, infectious, inflammatory, immunological, and degenerative factors may play an importante role in children. ${ }^{6}$

Definitions for basilar artery dolichoectsia vary according to studies. The mean diameter of the basilar artery at the level the pons is $3.17 \mathrm{~mm} .^{6}$ The vessel is considered elongetad when it's lateral to the clivus of the dorsum sellae, and dilated if its diameter exceeds $4.5 \mathrm{~mm} .^{4,6,7}$ Patients with normal basilar artery caliber, but with tortuosity, are more likely to have cranial nerve involvment alone, while those with vascular dilation without tortuosity generally develop compressive symptoms or neurological deficits due to ischemia. ${ }^{3}$

Studies have shown that ischemic stroke is the most common clinical manifestation of vertebro-basilar dolichoectasia and the most important cause of death in patients with this desease. The main subtype of ischemic stroke is posterior circulation ischemia, and vertebro-basilar dolichoectasia alone is already an independent risk fator for ischemia in this area. ${ }^{8}$ The seccond most frequent manifestation is the compression of cranial nerves. V and VII cranial pairs are the most affected and it results in trigeminal neuralgia and hemifacial paralisys. However, there may also be compression of the abducent, trochlear and oculomotor nerve. Compression of the brain stem in its lower portion can lead to nystagmus, tinnitus, dysphagia and dysphonia. ${ }^{4}$ When compressively affected, the VIII pair can also cause vestibular paroxysm, a pathology initially discribed in 1984 by Jannetta as at least 10 spontaneous or semi-spontaneous rotatory vertigo attacks, lasting less than 1 minute, stereotyped phenomenology, positive response to treatment with carbamazepine or oxacarbamazepine with no other diagnostic hypotesis to better explain the patient's clinic. ${ }^{9}$

Intracranial hemorrhagy is also an equally frequent manifestation when compared to nerve compression in cases of basilar artery dolichoectasia. However, it must be noted that this vasculopathy can present itself with numerous other symptoms as well as being asymptomatic. ${ }^{4}$

Involvment cases of III, IV, VII, IX an X cranial pairs by compression are rare. ${ }^{10}$

Therefore, we bring to discussion a basilar dolichoectasia case report discovered after ischemic event that evolved with hypoacusis and left peripheral facial paralysis associeted with dizziness and previous history of hearing loss in the right ear without defined ethiology.

The reported patient had VIII and VII cranial pairs affection after the stroke. As a result of this, he presented hearing loss and hemifacial paralysis both on the left side. This situation is justified once the path and anatomy of the nerves are analyzed together with the result of the acute ischemic injury located at the pons and base of left cerebellar hemisphere. However it has to be questioned whether the origin of contralateral hearing loss could be related to the vascular alteration. The result obtained in the patient's ECochG and the fluctuating character of the hearing loss found in the audiometries on the right side is compatible with endolymphatic hydrops, however in the MRI the aberrant basilar artery is in close contact with the VIII pair, which could generate a compressive effect on this nerve.

The labyrinthine artery can be highly variable in its origin. It can be a branch of the basilar artery or, as in most of the cases, it can be a branch from the anterior cerebellar artery. ${ }^{11,12}$

However, there are studies that show that the prduction of endolymph by the vascular stria, does not present any changes from abnormal arterial flow of the vertebro-basilar system. When discussing Meniére's disease, Lopes-Escamez et al. ${ }^{13}$ mentions cerebral vascular diseases as a possible diferencial diagnosis (stroke/transient ischemic attack on vertebro-basilar system). Audiological and vestibular symptoms, when presented together, are quite charcteristic of cerebral vascular disease, since the blood suply of the inner 


\section{Clinical Case}

ear derives from the vertebro-basilar circulation. Still on the diferencial diagnoses of Meniére's disease, the author exposes in his article the possibility of the compressive effect being generated by masses that may arise in the pontocerebellar angle in addition to the neurovascular compression syndrome (vestibular paroxysm). ${ }^{13}$ However it does not mention whether an alteration such as dolichoectasia basilar itself could simulte endolinphatic hydrops, either by vascular hypoflow or by mass effect.

Angiography is considered the gold standard for diagnosing vertebro-basilar dolichoectasia, on the other hand, MRI was cited as the exam of choice in most services, due to the possibility of better assessing the relationship between vascular structures and brains tissues. ${ }^{14}$ BERA can also be considered for investigation of asymetric hearing loss associeted with basilar dolichoectasia. $^{2}$

Adequate treatmente for the condition under discussion remains a dilema. Patients who have already presented ischemia or are carriers of intravascular thrombus, can be treated with anticoagulants and atiplatelets agentes, however the mechanical distortion of the vessel contributes to ischemic strokes and therefore it is questionable whether the treatment with these medications in fact gets the desired effetc. ${ }^{4}$ We can still highlight that this therapy increases the risk for hemorrhagic episodes. ${ }^{15,16}$

Patients with compressive neurological manifestations should probably have a surgical evaluation. Surgical decompression of the cranial nerve can be achived by repositioning the artery.
For patients with cerebrovascular complications, tratment should be based on care practice for patients with hemorrhagic or ischemic stroke. ${ }^{16}$

Among individuals with newly diagnosed vertebro-basilar dolichoectasia, it is recomended to screen for other potentially fatal arterial disorders. In young individuals with no vascular risk factors, primary predisposisng conditions such as Marfan, Fabry and Pompe's disease beginning in adulthood, should be considered. Serial imaging exams are recomended every six months and therafter, annual follow-up to monitor vessel enlargement. ${ }^{16}$

\section{Conclusion}

Basilar artery dolichoectasia is still a rare entity and very little explored both in clinical and therapeutic settings. Its presentation, associated with otorhinolaryngological signs and symptoms, is even less common.

It is very importante that the otorhinolaryngologist is awere of the ethyological possibility of this pathology during his anamnesis and physical examination, as it may be responsable for a range of conditions within otoneurology (tinnitus, dizziness, hearing loss, among others). A situation like that, in the eyes of a less experienced specialist, may go unnoticed and result in a more severe and possibly fatal condition.

The protocol tratment for these patients still remains very uncertain, each case has its specificities, and patient must be treated according to them. In conclusion, we emphasize the importance of a multidisciplinary approach in all cases.

\section{References}

1. Najafi MR, Toghianifar N, Esfahani MA, et al. Dolichoectasia in Vertebrobasilar Arteries Presented as Transient Ischemic Attacks: A Case Report. ARYA Atherosicer (Isfahan). 2016; 12(1):55-58.

2. Melo AA. Dolicomega da artéria vértebro-basilar como causa de perda auditiva neurossensorial assimétrica: relato de caso. Braz J Otorhinolayngol. (São Paulo).2011;15(3):385-387.

3. Mohammed K, Iqbal J, Kamel H, et al. Obstructive hydrocephalus and facial nerve palsy secondary to vertebrobasilar dolichoectasia: Case Report. Surg. Neurol. Int. (Doha). 2018;9:60.

4. Alabri H, Lewis WD, Manjila S, et al. Acute Bilateral Ophthalmoplegia Due to Vertebrobasilar Dolichoectasia: A Report of Two Cases. Am. J. Case Rep. 2017;18:1302-1308.

5. Ortak H, Tas U, Aksoy DB, et al. Isolated Upgaze Palsy in a Patient with Vertebrobasilar Artery Dolichoectasia: a Case Report. J Ophthalmic Vis Res (Totak). 2014;9(1):109-112.

6. Tuzcu EA, Bayarogullari H, Coskun M, et al. Bilateral Abducens Paralysis Secondary to Compression of Abducens Nerve Roots by Vertebrobasilar Dolichoectasia. Neuroophthalmology (Hatay). 2013;37(6):254-256.

7. Yuan Y, Xu K, Luo Q, et al. Research Progress on Vertebrobasilar Dolichoectasia. Int J Med Sci (Changchun). 2014;11(10):1039-1048.

8. Wang F, Hu XY, Wang T. Clinical and imaging features of vertebrobasilar dolichoectasia combined with posterior circulation infarction: A retrospective case series study. Medicine (Baltimore). 2018;97(48):e13166.

9. Jannetta PJ, Moller MB, Moller AR. Disabling Positional Vertigo. N Engl J Med (Pittsburgh). 1984;310:1700-1705.

10. Pham T, Wesolowski J, Trobe JD. Sixth cranial nerve palsy and ipsilateral trigeminal neuralgia caused by vertebrobasilar dolichoectasia. Am J Ophthalmol Case Rep (Michigan). 2018;10:229_ 232.

11. Zemlin WR. Princípios de anatomia e fisiologia em fonoaudiolo- 
Tuani A. Stroke e cols • Basilar dolichoectasia with otorhinolaryngological symptoms

gia. Artes Médicas (Porto Alegre).2000;4(5):338-44.

12. Hain TC, Ramaswamy TS, Hillman MA. Anatomia e fisiologia do sistema vestibular normal. In: HERDMAN, S.J. Reabilitação vestibular. Manole (São Paulo). 2002;1(1):3-23.

13. Lopes-Escamez JA, Carey J, Chung W, et al. Diagnostic criteria for Menière disease. J Vestib Res. (Granada). 2015;25:1-7.

14. Han J, Wang T, Xie Y, et al. Successive occurrence of vertebrobasilar dolichectasia induced trigeminal neuralgia, vestibular paroxysmia and hemifacial spasm: A case report. Medicine (Baltimore). 2018;97(25):e11192.

15. Yuan F, Lin J, Ding L, et al. Hemifacial spasm and recurrent stroke due to vertebrobasilar dolichoectasia coexisting with saccular aneurysm of the basilar artery: a case report. Turk Neurosurg. (Cheng Du). 2013;23(2):282-284.

16. Del Brutto VJ, Ortiz JG, Biller J. Intracranial Arterial Dolichoectasia. Front Neurol. (Chicago). 2017;8:344. 